Journal of Engineering and Applied Sciences 15 (6): 1385-1392, 2020

ISSN: 1816-949X

(C) Medwell Journals, 2020

\title{
Estimation of Electricity Production from Corn Residues: A Case Study of Nigeria
}

\author{
${ }^{1}$ Yekini Suberu Mohammed, ${ }^{2}$ Aminu Asumo Maruf, ${ }^{1}$ Caleb Akezi Amlabu, \\ ${ }^{1}$ James Gaina Bashayi, ${ }^{1}$ Yusuf Yunusa Sanni and ${ }^{1}$ Audu Nasiru \\ ${ }^{1}$ Centre for Research and Innovation, Federal Polytechnic Nasarawa, Nasarawa State, Nigeria \\ ${ }^{2}$ Department of Electrical and Electronic Engineering, Faculty of Engineering, \\ Nile University of Nigeria, Abuja, Nigeria
}

\begin{abstract}
Presently, Nigeria's energy security severely relies on costly imported fossil fuels. As a response to this constraint, the government is currently promoting research and development of renewable and sustainable energy. On a global scale, amidst global fossil fuel depletion situation and critical environmental pollution orchestrating from combustion of the fossil fuels, focus on renewable energy development is becoming unavoidable. Development of renewable energy is a desirable step towards minimizing the impact of fossil energy on the environment in the context of clean development mechanism. In this study, typical energy characteristics of biomass corn residues (cob, straw and stalk) were investigated in order to determine their suitability for power generation. Results indicated that the biofuel properties of the residues evidently presented the that they are suitable feedstock for power generation. In addition, the framework of the study also performs the estimation of bioenergy potential of the selected residues. It was found that with just $50 \%$ leftover availability factor $\left(\beta_{\mathrm{LAF}}=0.5\right)$, a significant amount of the national electricity demand can be met if the residues are utilized for rural electrification in the country.
\end{abstract}

Key words: Corn, cob, straw, stalk, bioenergy, renewable, electricity

\section{INTRODUCTION}

Biomass are energy based materials from biodegradable plant and animal residues. Biomass like other renewable sources of energy have proven tendency for reduction of global anthropogenic Greenhouse Gases (GHGs), especially when they are used in sustainable energy facilities. Williams et al. (2016) stated that biomass materials from agricultural residues are described as environmentally friendly sources of fuel for power generation and production of bio-chemicals. The technical and economic sustainability of biomass for power generation have been disclosed in some recent publications (Situmorang et al., 2019; Anvari et al., 2019; Ahmed et al., 2019). Unlike wind and solar energy systems, electricity generation from biomass offers the advantage of non-intermittency and easy control of energy produced as reported by Stich et al. (2017). Application of agricultural residues for power generation is one of the major steps towards reduction of environmental pollution considering the fact that open burning of the residues is harmful to the natural environment. Dumping of post-harvest agricultural residues in landfills contributes to the production of biogenic methane. Emissions of landfill methane gas is one of the main causes of increasing Global Warming Potential (GWP).
The benefits obtainable from the utilization of different biomass energy resources have made them progressively more substantial part of the global energy generation, especially in developing countries. Agricultural biomass from plants and animal wastes materials have been used for energy in rural areas for hundreds of years ago. Although, in the last few decades they have not been used in environmentally sustainable approaches. In many developing countries of Sub-Saharan Africa (SSA), traditional use of biomass for energy application is quite predominant. It was reported that traditional use of biomass for heating and cooking can exposedomestic people to ambient hazardous particulate emissions with ability to destroy respiratory systems (Zhang et al., 2012; Carter et al., 2018). Though, the penetration of modern energy technologies has pave ways for sustainable development of biomass energy systems. It is no doubt that biomass can contribute to energy generation, especially in agricultural based developing countries. However, a critical issue is that the amount of energy generation from biomass will contribute to the global energy in the future will be determined by national and regional energy stakeholders in addition to international energy policies. Thus, this paper presents a study on the estimated potential contribution of biomass corn residues for renewable and sustainable power generation in Nigeria. 
(a)

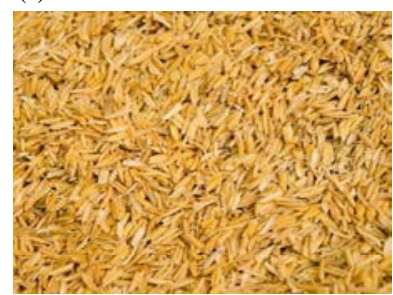

(d)

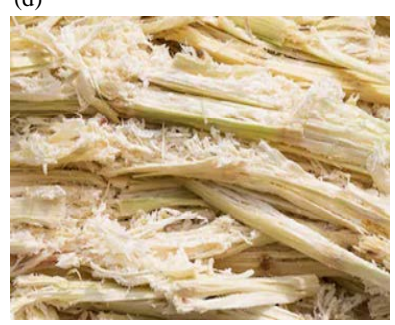

(g)

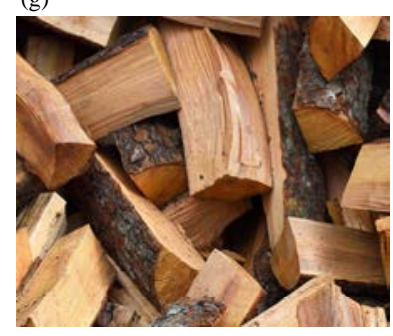

(b)

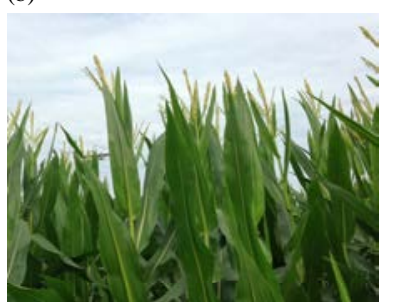

(e)

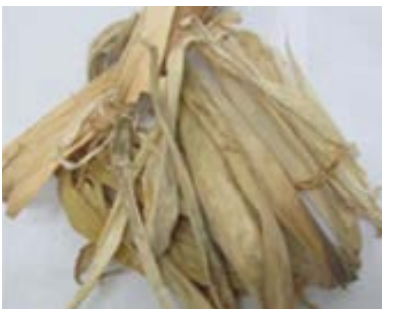

(h)

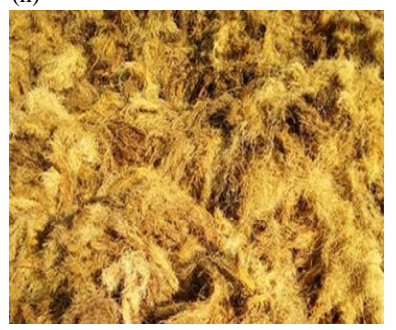

(c)

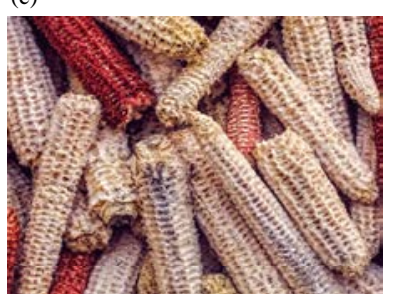

(f)

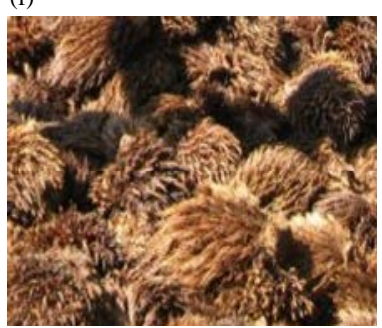

(i)

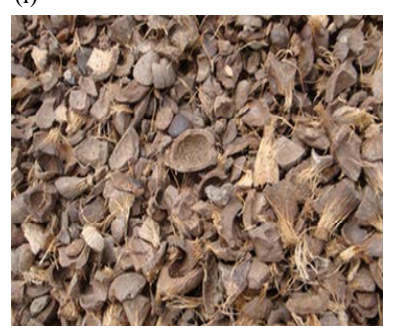

Fig. 1(a-i): Different categories of biomass residues for power generation (a) Rice husk, (b) Corn stalk, (c) Corn cob, (d) Sugarcane bagasse, (e) Corn straw, (f) Palm empty fruit bunch, (g) Forest firewood, (h) Palm pressed fiber and (i) Palm shell

\section{MATERIALS AND METHODS}

The methodology of this study include assessment of the availability of biomass corn residues in the Nigeria, presentation of concise overview of biomass conversion technologies, experimental characterization of biofuel properties of the selected corn residues and the theoretical estimation of the electrical energy potential of different residues.

Availability of biomass corn residues for power generation in Nigeria: agricultural biomass from crop residues encompasses agricultural residues generated from discarded agricultural post-harvest wastes such as rice husk, corn stalk, corn cob, sugarcane bagasse, corn straw, palm empty fruit bunch, forest firewood, palm pressed fibre and palm kernel shell shown in Fig. 1. Some agricultural crops produce more than one post-harvest residues. For example, corn produces cob, stalk and straw (husk) while rice produces husk and straw after harvest. Significant amounts of some agricultural wastes sometimes remain in the field after harvest. Harvesting of corn generates stalk and straw harvest residues while processing produces cob residues. These lignocellulosic biomass residues can conveniently be utilized for power
Table 1: Corn production quantity, area harvested and total yield

\begin{tabular}{lccc}
\hline Years & $\begin{array}{c}\text { Production quantity } \\
\left(\mathrm{P}_{\mathrm{ai}}\right) \text { (Tonne) }\end{array}$ & $\begin{array}{c}\text { Area harvested } \\
(\mathrm{hg} / \mathrm{ha})\end{array}$ & Yield (ha) \\
\hline 2011 & 8878456 & 5456540 & 16271 \\
2012 & 8694900 & 5751300 & 15118 \\
2013 & 8422670 & 5762700 & 14616 \\
2014 & 10058968 & 6346551 & 15850 \\
2015 & 10562050 & 6771189 & 15599 \\
2016 & 11547980 & 6600865 & 17495 \\
2017 & 10420000 & 6540000 & 15933 \\
\hline
\end{tabular}

generation using a wide range of modern waste-to-energy conversion technologies. Different biomass feedstocks are used for meeting variety of energy needs including electricity generation, domestic heating application, production of biofuels for automobiles and provision of process heat for industrial applications.

Being an agrarian nation, Nigeria is one of the major countries in Africa with anticipated bioenergy potential. The available corn residues in the country is estimated based on the annual crop production data from the Food and Agriculture Organization (FAO) statistics from 2011-2017 presented in Table 1. Considering the fact that some of the residues produced after harvesting and processing of the crop must be left on the field for maintenance of soil fertility, therefore, only a surplus 


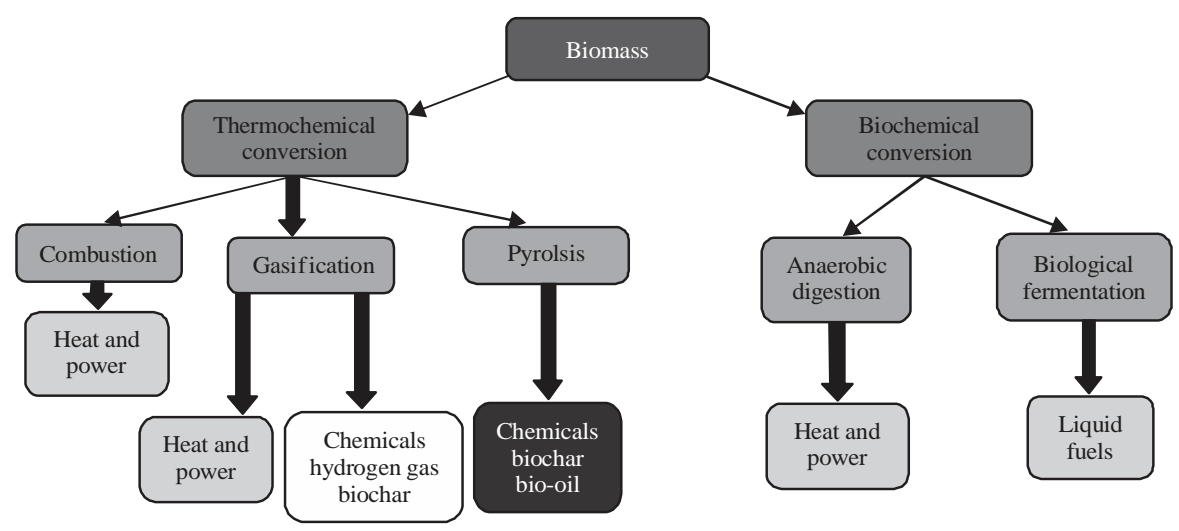

Fig. 2: Overview of modern biomass waste-to-energy conversion technologies

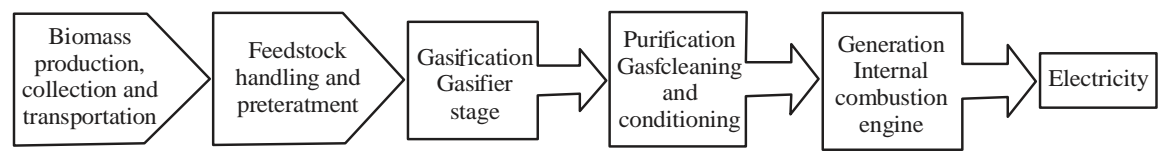

Fig. 3: Block diagram of biomass gasification for electric power generation

availability can be used for the purpose of energy. Thus, for the fact that, no data is available on the quantity of residues available for energy application in the country, a leftover availability factor $\left(\beta_{\mathrm{LAF}}\right)$ of $0.5(50 \%)$ is assumed for calculating the available Quantity of corn residues $\left(\mathrm{Q}_{\text {Res }}\right)$ in this study using Eq. 1:

$$
\mathrm{Q}_{\mathrm{Res}}=\mathrm{P}_{\mathrm{qj}} \times \mathrm{CRR} \times \beta_{\mathrm{LAF}}
$$

Where:

$\mathrm{P}_{\mathrm{qj}} \quad$ : The Production quantity of the corn crop under consideration

CRR : The Crop-to-Residue Ratio (describe as the quantity of residue produced by the crop)

Biomass conversion technologies: Modern biomass energy conversion technologies are mainly used for commercial production of energy for power generation, heat and fuels. Figure 2 presents the overview of modern biomass conversion technologies showing the portfolio of the end products of different conversion pathways. It was reported that by the end of 1990's, a potential installed capacity of $40 \mathrm{GW}$ electricity and $200 \mathrm{GW}$ heat production capacity from biomass energy conversion systems was achieved worldwide (Faaij, 2006). The beginning of year 2000 saw another advancement in biomass conversion technologies for large-scale sustainable power development due to evolving market and increasing quest for atmospheric decarbonisation. There is a likelihood that the actual role of biomass for power generation will be determined by its competitiveness with fossil based energy technologies in addition to favourable global agricultural policies. Many countries in the world have recognized the fact that biomass energy need to be modernized in order to key into the agenda of sustainable development mechanism.

Gasification: Gasification is the process of converting solid biomass residue for production of combustible gas (Nunes et al., 2016) for heat and power generation. Gasification requires limited oxygen than required for complete combustion biomass for power generation. The biodegradable substance in biomass feedstock is converted into combustible methane gas with some other gaseous impurities (Ravindranath and Hall, 1995; Tripathi et al., 1997; Purohit, 2009) at high temperature (Din and Zainal, 2016). The block diagram of a gasification process is shown in Fig. 3. It is most ideal to clean the methane gas produced from the gasification process prior to its application in an internal combustion engine to avoid some technical and operational constraints. Gasification of biomass can also be accomplished using Biomass Integrated Gasification Combined Cycle (BIGCC) plant. In some developing countries in Africa like Ghana, Uganda and Ethiopia, application of small scale biomass gasification systems have received major support for rural electrification from the government. In Europe, different kind of existing gasifiers (fixed bed, downdraft and updraft) have been tested successfully for small scale rural electrification using gas engines. Apart from the utilization of biomass gasification process for power generation, gasifiers have also been used for heat production. In recent times, gasification of biomass agricultural wastes for power generation in developing countries have received some 


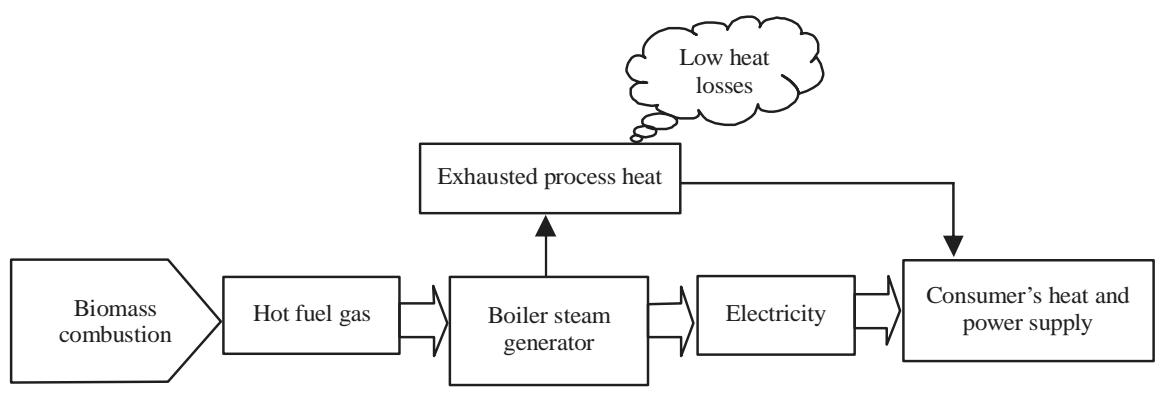

Fig. 4: Block diagram of pathways to electricity generation from pyrolysis

important financial support from international organizations such as the World Bank and the United Nations. In Nigeria, Ebonyi state (Ekwashi Ngbo), a rice-husk biomass gasification power plant with electrical power capacity of $25 \mathrm{~kW}$ has been established by United Nations agency in collaboration with the state government (Naqvi et al., 2017) but the system is yet to be commissioned for full operation.

Combustion: Biomass combustion systems are commonly utilized for power generation, production of heat or heat and power in a Combined Heat and Power (CHP) system. Combustion commonly known as biomass direct combustion burn biomass feedstock directly to yield high-pressure steam to drive an electric turbine for power generation. Combustion process occurs at a very high temperature $800-1000^{\circ} \mathrm{C}$ (Muhammad et al., 2017) to produce steam for power (Singh and Shukla, 2017). As an additional benefit, the process heat generated during a direct-fired combustion can be captured to improve the system efficiency. Heat generated by a biomass combustion system can be utilized for heating buildings or other application in industrial processes. Figure 4 shows the block diagram of biomass combustion technology with captured process heat. A simple biomass combustion system has fuel storage and handling unit, biomass combustor (furnace), generator, steam turbine, boiler, pumps, fans, condenser, cooling system, exhaust and automatic control system. In biomass combustion system, feedstocks are burnt inside the furnace for the production of hot gas. The hot gas is then injected into a boiler to produce steam. The steam is expanded to operate a steam turbine to generate electricity. A biomass combustion system yields to suitable economic performance at a potential above $2 \mathrm{MW}$ of electrical power.

Pyrolysis: This biomass conversion technique yields bio-oil and some other by-products by rapid heating of biomass feedstock in absence of oxygen via. a series of chemical reactions. Pyrolysis yields bio-char, fuel gas or bio-oil at different chemical conditions and temperature variation. At high temperature $\left(500-800^{\circ} \mathrm{C}\right)$, biomass

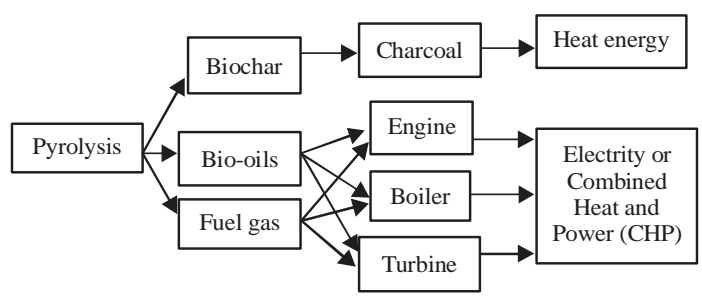

Fig. 5: Block diagram of pathways to electricity generation from pyrolysis

feedstock undergoes thermal decomposition to produce biogas, biofuels and solid biochar products (Yildiz et al., 2016). Figure 5 presents different pathways to electricity generation from pyrolysis. It is however stated that in a process of pyrolysis, about $40-75 \%$ biofuel is produced (Tsai et al., 2007; Uzun et al., 2006; Acikgoz et al., 2004). Agricultural and other biodegradable wastes are common bioenergy feedstocks for pyrolysis (Kosov et al., 2016; Kumaravel et al., 2016; Krutof and Hawboldt, 2016; Yildiz et al., 2016; Tripathi et al., 2016). On a global scale, pyrolysis for power generation is practically immature unlike other biomass power conversion technologies. Basically, the thermochemical process of pyrolysis could either be a fast or slow method. Fast pyrolysis yields a higher percentage of bio-oil (60\%) within a very short period of time usually in seconds while slow pyrolysis take longer time to complete its associated chemical processes thereby producing more bio-char than oil. Irrespective of the pyrolysis process, electricity can be generated from the application of the biogas or bio-oil in a steam boiler. Pyrolysis based power plants perform with greater reliability at a capacity above 2 MW scale. Contrarily in gasification power plants, increasing capacity above 2 MW of electric power could result in technical operational difficulties. Thus, it could be stated that pyrolysis takes off where gasification fails on technical ground.

Fuel characteristics of the selected corn residues for energy application: Corn residue samples (cob, stalk and straw) were collected from a local farmland in Federal 
Polytechnic Nasarawa located in Northcentral Nigeria. They were separated and dried outdoors for a period of 4 weeks in order to reduce their moisture content. The samples were then prepared by milling to convenient particle diameter of $0.35-0.42 \mathrm{~mm}$ for ease of handling by the experimental instruments. An IKA C2000 bomb calorimeter was used to determine the Lower Heating Value( LHV) of the residues. The proximate and ultimate analysis of the residues were performed experimentally using ASTM D3137 and ASTM D5373, respectively. The Sulphur (S) content of the residues was determined using ASTM D3177. The percentage of oxygen content was determined by calculating the difference in the elemental contents. The estimation for the energy production is calculated using the Eq. 2:

$$
\mathrm{E}_{\mathrm{P}}=\sum_{\mathrm{j}}^{\text {crop }} \mathrm{Q}_{\mathrm{Res}} \times \mathrm{LHV}_{\mathrm{kj}}
$$

where, $\mathrm{LHV}_{\mathrm{kj}}$ is the Lower Heating Value of $\mathrm{k}$ residue from j crop.

\section{RESULTS AND DISCUSSION}

This segment of the study presents the findings and discussion with reference to existing literature work.

Estimation of available corn residues: The estimated quantity of the residues generated is calculated based on the Crop-to-Residue (CRR) factors of each of the residues as sourced from literature. The CRR used for the estimation of cob residue is 0.29 (Kartha and Larson, 2000), 0.2 for straw (Jekayinfa and Scholz, 2009) and 1.5 for stalk (OECD/IEA., 2010; Duku et al., 2011). The CRR is the amount of residue produced per unit mass of the crop. The results of the estimated quantity of different categories of the residues are presented in Table 2.

Fuel characterization of the residues: The elements of proximate analysis, ultimate analysis and heating (calorific) value are used basically to characterise the performance of solid biomass fuels when they are heated for the energy production. Proximate and ultimate analysis are essential indicators that describe the fuel characteristics of any biomass residue used for energy in modern conversion systems. Contrary to the traditional method of using biomass for energy which is typically an inefficient method, the performance of a biomass feedstock for power generation critically depends on the Moisture Content (MC) as well as the Volatile Matter Content (VMC) of the fuel. The results of the fuel analysis of the selected corm residues are shown in Table 3 and 4 for proximate and ultimate analysis, respectively. Proximate analysis of the residues gives the
Table 2: Estimated biomass corn residues based on leftover availability factor $\left(\beta_{\mathrm{LAF}}=0.5\right)$

Maize (corn) Estimated $\quad$ Estimated $\quad$ Estimated
production cob residues straw residue stalk residue \begin{tabular}{lcccc} 
Years & quantity (Tonne) & $(\mathrm{Gg})$ & $(\mathrm{Gg})$ & $(\mathrm{Gg})$ \\
\hline 2011 & 8878456 & 1287.4 & 887.8 & 6658.8
\end{tabular}

$\begin{array}{lllll}2012 & 8694900 & 1260.8 & 869.5 & 6521.2\end{array}$

$\begin{array}{lrrrr}2013 & 8422670 & 1221.3 & 842.3 & 6317.0\end{array}$

$\begin{array}{lllll}2014 & 10058968 & 1458.6 & 1005.9 & 7544.2\end{array}$

$\begin{array}{lllll}2015 & 10562050 & 1531.5 & 1056.2 & 7921.5\end{array}$

\begin{tabular}{lllll}
2016 & 11547980 & 1674.5 & 1154.8 & 8661.0 \\
\hline
\end{tabular}

\begin{tabular}{lllll}
2017 & 10420000 & 1510.9 & 1042.0 & 7815.0 \\
\hline
\end{tabular}

Table 3: Measured proximate analysis of the residues

\begin{tabular}{lccc}
\hline Parameters & Corn cob & Corn stalk & Corn straw \\
\hline Moisture Content (MC) & 6.10 & 6.12 & 5.92 \\
Volatile Matter (VM) & 65.10 & 67.30 & 68.50 \\
Ash Content (AC) & 8.50 & 7.25 & 7.38 \\
Fixed Carbon (FC) & 20.30 & 19.33 & 18.20 \\
\hline
\end{tabular}

Table 4: Measured ultimate analysis of the residues

\begin{tabular}{lrcc}
\hline Parameters & Corn cob & Corn stalk & Corn straw \\
\hline Carbon (C) & 44.20 & 44.51 & 44.01 \\
Hydrogen (H) & 5.80 & 5.48 & 5.41 \\
Nitrogen (N) & 0.70 & 0.19 & 0.26 \\
Sulphur (S) & 1.20 & 1.74 & 0.93 \\
Oxygen (O) & 48.10 & 48.08 & 49.39 \\
\hline
\end{tabular}

percentage of the residues that burn in a solid state (fixed carbon) in gaseous state (volatile matter) and the percentage of inorganic waste component (ash) (Anukam et al., 2017) including the moisture content. On the other hand, the ultimate analysis is the determination of the compositional elements of the solid biofuel materials. The calorific value of a biomass residue is the heating value of the residues that represent the amount of the chemical energy stored in the fuel. The basic elements of solid biomass fuels consist of Nitrogen (N), Sulphur $(\mathrm{S})$, Hydrogen $(\mathrm{H})$, Oxygen $(\mathrm{O})$ and Carbon $(\mathrm{C})$. In the computation of bioenergy potential of solid biofuels, the Net Calorific Value (NCV) which is the Lower Heating Value (LHV) of the fuel is used. The reason is that the quantity of heat released per unit mass of the fuel is less than the Gross Calorific Value (GCV) or High Heating Values (HHV) due to the formation of water vapour from the latent heat of condensation. Therefore, the Lower Heating Value (LHV) of the residues measured in $\mathrm{MJ} / \mathrm{kg}$ for $\mathrm{LHV}_{\text {cob}}, \mathrm{LHV}_{\text {straw }}$ and $\mathrm{LHV}_{\text {stalk }}$ are 15.7, 12.2 and $15.3 \mathrm{MJ} / \mathrm{kg}$, respectively. LHV of a biofuel is the most essential parameter in a thermochemical or biochemical bioenergy conversion. The LHV of most bioenergy resources range from 8-20 MJ/kg, therefore, the values obtained in this study can be adjudge suitable in the energy conversion of the selected agricultural residues.

Apart from the LHV which determines the thermochemical characteristics of a biofuel, some biochemical properties such as ash content, moisture content and volatile matter are very important factors. 
J. Eng. Applied Sci., 15 (6): 1385-1392, 2020

\begin{tabular}{lccccc}
\multicolumn{7}{c}{ Table 5: Theoretical bioenergy } & potential of the corn residues \\
\hline $\begin{array}{c}\text { Corn } \\
\text { production } \\
\text { quantity } \\
\text { (Tonne) }\end{array}$ & $\begin{array}{c}\text { Cob } \\
\text { bioenergy } \\
\text { potential } \\
\text { (PJ) }\end{array}$ & $\begin{array}{c}\text { Straw } \\
\text { bioenergy } \\
\text { potential } \\
\text { (PJ) }\end{array}$ & $\begin{array}{c}\text { Stalk } \\
\text { bioenergy } \\
\text { potential } \\
\text { (PJ) }\end{array}$ & $\begin{array}{c}\text { Total } \\
\text { bioenergy } \\
\text { potential } \\
\text { (PJ) }\end{array}$ \\
\hline Years & 8878456 & 20.2 & 10.8 & 101.9 & 132.9 \\
2011 & 8694900 & 19.8 & 10.6 & 99.8 & 130.2 \\
2013 & 8422670 & 19.2 & 10.3 & 96.7 & 126.2 \\
2014 & 10058968 & 22.9 & 12.3 & 115.4 & 150.6 \\
2015 & 10562050 & 24.0 & 12.9 & 121.2 & 158.1 \\
2016 & 11547980 & 26.3 & 14.1 & 132.5 & 172.9 \\
2017 & 10420000 & 23.7 & 12.7 & 119.6 & 156.0 \\
\hline
\end{tabular}

Deposition of ash particles causes serious obstruction and operational constraints in gasifiers systems. Apart from the gasifier, ash deposit also results in damaging of other salient parts of biomass utilization equipment such as burner, heat exchanger, boiler and exhaust systems (Mayrou, 2006). The values obtained for the moisture content of the residues as shown in Table 3 are generally, $<10 \%$. These values are considerably good, since, an increase in humidity of biomass residues from $0-40 \%$ reduces its LHV by $66 \%$ and energy efficiency. The percentage of humidity differentiate between wet and dry biomass feedstock. Wood has an average moisture content between 40 and 50\% (Alatzas et al., 2019) but still can be converted to bioenergy using thermochemical processes. However, at higher percentage moisture content (above $50 \%$ ), biomass materials like animal manure utilizes biochemical anaerobic digestion as high humidity has negative influence on the technical operations of thermochemical conversion engines. The volatile matter content of a biomass residue is the characteristic property of the residue that represents the condensable and non-condensable vapour generated when the residue is heated at high temperature. The high volatile matter contents of the residues obtained in this study are relatively expected because of the organic nature of the materials. High percentage of VM is an indicator of better gasification and combustion rate for energy production because of the high energy yield upon carbonization (Jenkins et al., 1998).

Estimated bioenergy potential of the residues: A close look at the results presented in Table 5 disclose that the estimated potential of bioenergy from stalk residue is three times greater than the total sum of the potential from cob and straw residues combined together. This is probably due to the high value of CRR of the stalk residue. The estimated bioenergy potential calculated for a period of 7 years has the highest value of approximately $173 \mathrm{PJ}$ in 2016. This value corresponds to estimated 48 TWh of electricity as shown in Fig. 6. The 2011 and 2012 estimated electrical energy values are both 36 TWh but a slight drop was observed in 2013. In 2014, there is a conspicuous increase in the estimated energy potential of the total biomass residues by 6 TWh as observed in Fig. 6. From 2014-2016, a non-uniform steady growth is observed but declined to the same amount of estimated energy of 43 TWh recorded for the year 2015.

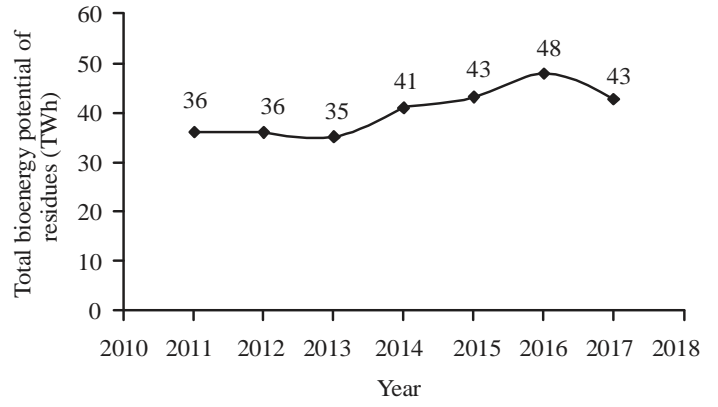

Fig. 6: Total theoretical electrical energy potential of the corn residues

Furthermore, if biomass power plants utilizing the biomass residues are to work the year round, the equivalent of the gross theoretical energy potential presented in Table 5 will yield 4109, 4109, 3995, 4680, 4908, 5479 and 4908 MW for year 2011-2017, respectively. The current available capacity of power generation in the country is around 4000-5000 MW. Therefore, from the estimates of energy presented for the residues for a period of 7 years, it can be stated that the selected residues have sustainable potential for power generation in the country.

\section{CONCLUSION}

Going by the present techno-economic scenario in the country, establishment of centralize power generation using the bioenergy residues is not feasible. However, since, agricultural residues are generated in many rural communities that are off-grid, therefore, utilization of the residues for decentralized power generation should be a key focus. Considering the biomass conversion technological options highlighted in this study, biomass gasification could be the most suitable approach to be adopted. The is based on the ability of gasifier systems to produce syngas with low-tar impurities and high calorific value for electricity generation. The technical and economic analyses of biomass gasification for rural power generation in Nigeria has been established by Sobamowo and Ojolo (2018). A typical rural power demand in Nigeria range from 10-100 kW. It has also being established that small scale power demand can be supplied economically using a biomass downdraft gasification system (Mohammed et al., 2017). Therefore, this study presents that Nigeria has suitable potential for bioenergy using the corn residues. For the reason that biomass agricultural residues are freely available in the country for now, government and energy stakeholders in the country can create enabling techno-economic conditions for their application for power generation.

\section{RECOMMENDATIONS}

Small scale gasification power plants can be operated in the rural areas where the bioenergy residues are 
generated due to the flexibility of collection, transportation and storage of the biofuels. Considering the fact that, rural communities in Nigeria hold the key to sustainable agricultural production, there are needs to provide steady power to support livelihood and modernization of agricultural activities. Apart from solar energy currently being harnessed for rural electrification in the country, small scale biomass can function to support availability of modern energy in rural communities. Consequently, implementation of small scale biomass gasification plants in rural areas could help the government to move closer towards accomplishing the pursuit for sustainable development and employment generation.

\section{ACKNOWLEDGEMENTS}

The researchers would like to thank the Tertiary Education Trust Fund (TETFund), Nigeria, for its financial support through Institution Based Research (IBR) grant.

\section{REFERENCES}

Acikgoz, C., O. Onay and O.M. Kockar, 2004. Fast pyrolysis of linseed: Product yields and compositions. J. Anal. Applied Pyrol., 71: 417-429.

Ahmed, O.Y., M.J. Ries and W.F. Northrop, 2019. Emissions factors from distributed, small-scale biomass gasification power generation: Comparison to open burning and large-scale biomass power generation. Atmos. Environ., 200: 221-227.

Alatzas, S., K. Moustakas, D. Malamis and S. Vakalis, 2019. Biomass potential from agricultural waste for energetic utilization in Greece. Energies, Vol. 12, No. 6. 10.3390/en12061095

Anukam, A.I., B.P. Goso, O.O. Okoh and S.N. Mamphweli, 2017. Studies on characterization of corn cob for application in a gasification process for energy production. J. Chem., Vol. 2017, $10.1155 / 2017 / 6478389$

Anvari, S., S. Khalilarya and V. Zare, 2019. Power generation enhancement in a biomass-based combined cycle using solar energy: Thermodynamic and environmental analysis. Applied Therm. Eng., 153: 128-141.

Carter, E., M. Shan, Y. Zhong, W. Ding, Y. Zhang, J. Baumgartner and X. Yang, 2018. Development of renewable, densified biomass for household energy in China. Energy Sustainable Dev., 46: 42-52.

Din, Z.U. and Z.A. Zainal, 2016. Biomass integrated gasification-SOFC systems: Technology overview. Renewable Sustainable Energy Rev., 53: 1356-1376.
Duku, M.H., S. Gu and E.B. Hagan, 2011. A comprehensive review of biomass resources and biofuels potential in Ghana. Renewable Sustainable Energy Rev., 15: 404-415.

Faaij, A., 2006. Modern biomass conversion technologies. Mitigation Adapt. Strategies Global Change, 11: 343-375.

Jekayinfa, S.O. and V. Scholz, 2009. Potential availability of energetically usable crop residues in Nigeria. Energy Sour. Part A: Recovery Utiliz. Environ. Effects, 31: 687-697.

Jenkins, B.M., L.L. Baxter, T.R. Miles Jr. and T.R. Miles, 1998. Combustion properties of biomass. Fuel Process. Technol., 54: 17-46.

Kartha, S. and E.D. Larson, 2000. Bioenergy Primer: Modernised Biomass Energy for Sustainable Development. United Nations Development Programme, New York, USA., ISBN: 9789211261271, Pages: 133.

Kosov, V.F., V.A. Lavrenov, O.M. Larina and V.M. Zaichenko, 2016. Use of two-stage pyrolysis for bio-waste recycling. Chem. Eng. Trans., 50: 151-156.

Krutof, A. and K. Hawboldt, 2016. Blends of pyrolysis oil, petroleum, and other bio-based fuels: A review. Renewable Sustainable Energy Rev., 59: 406-419.

Kumaravel, S.T., A. Murugesan and A. Kumaravel, 2016. Tyre pyrolysis oil as an alternative fuel for diesel engines-A review. Renewable Sustainable Energy Rev., 60: 1678-1685.

Mayrou, E., 2006. [Biomass combustion cogeneration technologies in Europe]. Master's Thesis, Department of Mineral Resources Engineering, University of Crete, Chania, Greece. (In Greek)

Mohammed, Y.S., M.W. Mustafa, N. Bashir and I.S. Ibrahem, 2017. Existing and recommended renewable and sustainable energy development in Nigeria based on autonomous energy and microgrid technologies. Renew. Sustain. Energy Rev., 75: 820-838.

Naqvi, M., E. Dahlquist and J. Yan, 2017. Complementing existing CHP plants using biomass for production of hydrogen and burning the residual gas in a CHP boiler. Biofuels, 8: 675-683.

Nunes, L.J.R., J.C.O. Matias and J.P.S. Catalao, 2016. Biomass combustion systems: A review on the physical and chemical properties of the ashes. Renewable Sustainable Energy Rev., 53: 235-242.

OECD/IEA., 2010. Sustainable production of second-generation biofuels: Potential and perspectives in major economies and developing countries: Information Paper. OECD/IEA, Paris, France.

Purohit, P., 2009. Economic potential of biomass gasification projects under clean development mechanism in India. J. Clean. Prod., 17: 181-193.

Ravindranath, N.H. and D.O. Hall, 1995. Biomass Energy and Environment: A Developing Country Perspective From India. Oxford University Press, Oxford. 
Singh, R. and A. Shukla, 2017. A review on methods of flue gas cleaning from combustion of biomass. Renewable Sustainable Energy Rev., 29: 854-864.

Situmorang, Y.A., Z. Zhao, A. Yoshida, Y. Kasai, A. Abudula and G. Guan, 2019. Potential power generation on a small-scale separated-type biomass gasification system. Energy, 179: 19-29.

Sobamowo, G.M. and S.J. Ojolo, 2018. Techno-economic analysis of biomass energy utilization through gasification technology for sustainable energy production and economic development in Nigeria. J. Energy, 2018: 1-16.

Stich, J., S. Ramachandran, T. Hamacher and U. Stimming, 2017. Techno-economic estimation of the power generation potential from biomass residues in Southeast Asia. Energy, 135: 930-942.

Tripathi, A.K., P.V.R. Iyer and T.C. Kandpal, 1997. A financial evaluation of biomass-gasifier-based power generation in India. Bioresour. Technol., 61: 53-59.
Tripathi, M., J.N. Sahu and P. Ganesan, 2016. Effect of process parameters on production of biochar from biomass waste through pyrolysis: A review. Renewable Sustainable Energy Rev., 55: 467-481.

Tsai, W.T., Lee and C.Y. Chang, 2007. Fast pyrolysis of rice husk: Product yields and compositions. Bioresour. Technol., 98: 22-28.

Uzun, B.B., A.E. Putun and E. Putun, 2006. Fast pyrolysis of soybean cake: Product yields and compositions. J. Biores. Technol., 97: 569-576.

Williams, C.L., T.L. Westover, R.M. Emerson, J.S. Tumuluru and C. Li, 2016. Sources of biomass feedstock variability and the potential impact on biofuels production. BioEnergy Res., 9: 1-14.

Yildiz, G., F. Ronsse, R. van Duren and W. Prins, 2016. Challenges in the design and operation of processes for catalytic fast pyrolysis of woody biomass. Renewable Sustainable Energy Rev., 57: 1596-1610.

Zhang, Q., K. He and H. Huo, 2012. Policy: Cleaning China's air. Nature, 484: 161-162. 